Биљана М. Радовановић ${ }^{1}$

Горан Ж. Ружић ${ }^{2}$

Универзитет у Нишу, Филозофски факултет
УДК 378.147:101.1]:316.64-057.875

Оригинални научни рад

Примљено: 16. 06. 2020.

https://doi.org/10.46630/gflz.3.2021.02

\title{
АНАЛИЗА РЕЗУЛТАТА АНКЕТА О СТУДЕНТСКИМ СТАВОВИМА ПОВОДОМ ПИТАҢА ИЗ МЕТОДОЛОГИЈЕ И ФИЛОЗОФИЈЕ НАУКЕ
}

\begin{abstract}
Ancтракт: Циљ овог рада је да се изврши квалитативна и квантитативна анализа резултата пројекта који је у оквиру истраживачког рада на Филозофском факултету Универзитета у Нишу спроведен ради праћења рада студената и оцене учинка појединих курсева филозофије на формирање и мењање ставова анкетираних. Наше основно питање је да ли новоусвојена знања из области методологије и филозофије науке утичу на уверења студената? Ако је тај учинак видљив, у ком правцу и којим интензитетом он иде? Користили смо метод анкете за спровођење истраживања и упоредни и статистички метод за обраду података. Добијени резултати су потврдили претпоставку, коју смо желели да испитамо, о значајном утицају курсева филозофије на формирање ставова студената. Усвојена знања из методологије и филозофије науке делују у правцу јачања критичке свести и недогматског приступања при разматрању конкретних проблема. Резултати су у сагласности с теоријским усмерењем целокупног студија филозофије као и конкретних циљева датих курсева (предочених у силабусима).
\end{abstract}

Кључне речи: филозофија, наука, филозофија науке, методологија, ставови, знање, критика.

\section{1. Увод}

Овај рад је резултат анализе добијених резултата у оквиру истраживачког пројекта који је реализован на Департману за филозофију у периоду школске 2018/2019. године на Филозофском факултету Универзитета у Нишу. У истраживању су учествовали студенти филозофије све четири године основних студија. Овај рад ће предочити добијене резултате поводом питања која се односе на проблеме науке и методологије научног рада. Поводом одговора који су овде дати анкетирани су студенти прве, друге и треће године.

Сваки студент је на идентичан начин шифрирао оба своја теста. Поводом поступка шифрирања добили су прецизна упутства. На тај начин смо обезбедили могућност примене упоредног метода у анализи резултата. Такође, могуће је изнети закључке о тенденцији правца у којем се развијају и мењају ставови студената уколико се упореде промене које су уочене код све три анкетиране године.

\footnotetext{
${ }^{1}$ biljana.radovanovic@filfak.ni.ac.rs

22 goran.ruzic@filfak.ni.ac.rs
} 
Намера овог рада је испитивање ставова и предрасуда везаних за науку и методолошке процесе научног рада. Дакле, истраживање нема за циљ да испита и процењује знање студената нити да да̂ оцену о успешности наставног процеса у усвајању знања. У том смислу су ставови формулисани тако да не представљају ни тачне ни нетачне исказе. Изнете тврдње су заоштрени ставови одређених филозофских школа, праваца и учења. Наиме, наша намера је била да поводом одређених децидираних екстремних ставова или широко распрострањених уверења у друштву која се односе на науку испитамо мишљења студената. Нагласак смо ставили на питања која се тичу поузданости научног знања и позиције и улоге науке у целокупном систему знања. Такође, разматрани су ставови који се односе на домете и границе примене науке као и етичка питања с којима се у свом раду суочавају: истраживачи, научници, научна заједница као и целокупна интелектуална јавност једног друштва.

Студенте свих година студирања анкетирали смо на почетку зимског и на крају летњег семестра. У обе анкете испитаници су добили идентична питања. Намера нам је да испитамо да ли су након слушања одређеног курса из филозофије студенти променили нека своја уверења? У којој мери је настава омогућила да се стекну шири увиди или да се ублаже неки до тада присутни ставови? Да ли нас филозофија учи да у животу проблемима, појавама и ситуацијама не приступамо на догматски начин? У којој мери филозофска знања отварају простор за свестраност приступа у настојању да се пронађу одговори на постављене изазове? Да ли студије подстичу критички начин размишљања и сагледавања проблема? Да ли може да се уочи изнијансираност у одговорима испитаника? Да ли нам филозофија омогућава да изградимо и учврстимо властито уверење о важним појавама и догађајима у свету?

Целокупна анкета има за циљ да на основу испитивања ставова студента добијене резултате користимо у циљу побољшања наставе и унапређења наставног процеса. Резултати су нам примарно важни ради праћења тенденција развоја односа између филозофских знања и личних ставова.

Међутим, један од бенефита овог истраживачког процеса не тиче се само наших запажања и резултата. Секундарно, ова анкета може и испитаницима бити корисна за сагледавања њиховог личног развоја. Испитивање може бити подстицајно за самоанализу, за праћење трансформације и развоја сопствених ставова, као и за дубље разумевање места свог начина размишљања у интелектуалној сфери друштва.

У наставку рада, у другом поглављу, ћемо навести сва питања која су из проблематике науке и методологије ушла у анкету, а затим ћемо описати њихов садржај и значај. Извршићемо и њихово груписање у пет категорија на основу тематске сличности. У наредном поглављу ћемо разматрати резултате истраживања по годинама студија. Такође, у овом делу рада ћемо кроз табеларни приказ свих одговора представити добијене резултате. Анализираћемо правце промене ставова студената и размотрићемо значења добијених разлика. За сваку анализирану годину навешћемо која директна и контекстуална знања могу извршити утицај на уверења студената. Крећемо са анализом одговора бруцо- 
ша, затим обрађујемо одговоре студената друге године и на крају предочавамо резултате на трећој години студија филозофије. У последњем, четвртом, делу ове студије изводимо конкретне закључке у односу на претпостављену хипотезу целокупног истраживања.

\section{2. Питања и њихова анализа}

У оквиру спроведеног истраживања на Департману за филозофију студентима су дата следећа питања која се односе на проблеме науке и методологије научног рада:

1. На сва питања човечанства се може одговорити научно, то је само питање тренутног стадијума развитка науке.

2. Резултати природно-техничких наука имају директнији утицај на наш живот од друштвено-хуманистичких.

3. Примена метода природних наука на друштвене и хуманистичке науке дала би значајне и поуздане одговоре на питања тих наука.

4. Научник не треба да се пита о могућим последицама својих истраживања и открића.

5. Искључиво научно-технички напредак побољшаће свеопшти животни стандард.

6. Научне методе могу увек да се сведу на непосредно искуство.

7. Наука и филозофија имају исту сферу проучавања.

8. Природно-техничке науке верно описују стварност каква она јесте.

9. Природно-техничке науке поузданије су од друштвено-хуманистичких.

10. Иако нису сасвим поуздане, индуктивне методе неопходне су у емпиријским наукама.

11. Постоје питања која не могу бити (само) научно одговорена.

12. Постоји линија несумњивог напретка у научном развитку.

13. Научно-технолошки развитак иде напоредно са моралним развитком човечанства.

Груписање тематски сродних питања

Направили смо 5 група (А, Б, Ц, Д, Е) питања на основу тематске повезаности.

Група А. Овај скуп питања односи се на проблем моћи науке да да̂ одговоре на све изазове који се пред њу постављају. Ови ставови се тичу утврђивања: граница, успеха, поузданости и домета процеса научног истраживања. Такође, испитујемо уверења студената по питању тога да ли наука може значајно да унапреди квалитет нашег живота, као и каква су предметна поклапања науке са другим духовним делатностима. У ову тематску групу спадају питања 1, 5, 7, 8 и 11. 
Група Б. Читав један сет ставова односи се на уверења или могуће предрасуде поводом доприноса природно-техничких и друштвено-хуманистичких наука. Упоређујемо које су науке поузданије, егзактније, да ли би друштвене науке требало да се угледају на природне науке и сл. О оваквим дилемама говоре питања 2, 3 и 9.

Група Ц. У оквиру овакве провере ставова било нам је важно и да испитамо уверења студената по питању одговорности научника за последице, утицај и примену резултата свога рада. У којој мери би научник требало да буде морално одговоран за последице и могуће (зло)употребе свога рада. Стога смо у ово истраживање уврстили питање 4 . Ово питање спада у ону групу упита који врше прелаз из једне у другу испитивану област (у овом случају реч је о етици).

Група Д. Везаност науке за искуство и емпиријске методе обраде података тематизује се у ставовима под 6 и 10 . У којој мери научне теорије могу да се сведу на емпиријске податке? Чему служи искуство када је наука у питању? Да се теорије генеришу одговарајућим методским поступцима из искуства или оно служи да се хипотезе на њему проверавају, потврђују или оповргавају?

Група Е. Питања 12 и 13 разматрају да ли наука у свом развоју напредује. Да ли је кроз историју науке могуће уочити континуитет и квалитативне помаке или су на делу смене несамерљивих научних парадигми? Може ли се говорити о кумулативности научног знања или је реч о дисконтинуираним епизодама гомилања података ради потврђивања доминантне теорије?

Распон понуђених одговора креће се на скали од 1 до 5 . Где је 1 - уопште се не слажем, 2 - већином се не слажем, 3 - нисам сигуран/-на, 4 - већином се слажем, 5 - у потпуности се слажем.

\section{2. Приказ резултата по годинама студија}

\section{I. Анализа одговора студената прве године}

У оквиру прве године студија бруцоши у зимском семестру слушају Увод у логику 1 а у летњем семестру Увод у логику 2. Поред базичних појмова из логике и основних форми ваљаног мишљења студенти се, у оквиру поменутих предмета, упознају са традиционалним учењем из области опште методологије. Овако конципиран студиј логике води порекло још из периода логике Port-Royal-a. У оквиру методолошког дела рада на предметима Увод у логику 1 и Увод у логику 2 усвајају се основна знања која се тичу структуре и процеса научног рада. Разматра се шта су: научна теорија, научни закон, научни систем... Учи се о елементима и врстама доказа и могућим погрешкама који се јављају у процесу утврђивања истинитости неке тезе. Ставови који се овде усвајају, пре свега, имају своје упориште у природним наукама ${ }^{3}$ и везани су за емпиријска истраживања: прикупљања чињеница, обраде добијених подата-

\footnotetext{
${ }^{3}$ У том смислу је за неко наредно истраживање остављено поље методологије и методолошких поступака у оквиру друштвених наука.
} 
ка, формулисања научних хипотеза и научних поступака њиховог тестирања и проверавања.

На првој години студија, у оквиру предмета Историја античке филозофије 1 и 2 обрађују се теме из античког периода. Тада се није правила разлика између науке и филозофије. Оне су сачињавале обједињени корпус знања који је морао да буде доказан, кохерентан, утемељен, изведен из искуства и примењен у пракси. У концепцијама великих филозофа антике: Сократа, Платона и Аристотела и појединих школа у хеленистичко-римском периоду сусрећемо различита разматрања која се односе на: врсте спознаје, поделу спознајних моћи, учење о методама, поделу знања.

Табела резултата одговора студената прве године

\begin{tabular}{|c|c|c|c|c|c|c|c|c|}
\hline & \multicolumn{6}{|c|}{ I godina } & \\
\hline & & 13040 & 12025 & \begin{tabular}{|l|}
06150 \\
\end{tabular} & 12060 & 04080 & $1316 / 40$ & \\
\hline \multirow{3}{*}{$\begin{array}{l}\text { Na sva pitanja čovečanstva se može odgovoriti } \\
\text { naučno, to je samo pitanje trenutnog } \\
\text { stadijuma razvitka nauke. }\end{array}$} & \multirow{3}{*}{7} & 2 & 3 & 1 & 2 & 4 & 4 & 2.67 \\
\hline & & 2 & 4 & 2 & 1 & 4 & 3 & 2.67 \\
\hline & & 0 & 1 & 1 & -1 & 0 & -1 & 0.00 \\
\hline \multirow{3}{*}{$\begin{array}{l}\text { Rezultati prirodno-tehničkih nauka imaju } \\
\text { direktniji uticaj na naš život od društveno- } \\
\text { humanističkih. }\end{array}$} & \multirow{3}{*}{12} & 4 & 1 & 3 & 4 & 4 & 3 & 3.17 \\
\hline & & 4 & 4 & 2 & 2 & 4 & 3 & 3.17 \\
\hline & & 0 & 3 & -1 & -2 & 0 & 0 & 0.00 \\
\hline \multirow{3}{*}{$\begin{array}{l}\text { Primena metoda prirodnih nauka na društvene } \\
\text { i humanističke nauke dala bi značajne i } \\
\text { pouzdane odgovore na pitanja tih nauka. }\end{array}$} & \multirow{3}{*}{18} & 2 & 1 & 3 & 3 & 2 & 4 & 2.50 \\
\hline & & 2 & 2 & 3 & 2 & 2 & 3 & 2.33 \\
\hline & & 0 & 1 & 0 & -1 & 0 & -1 & -0.17 \\
\hline \multirow{3}{*}{$\begin{array}{l}\text { Naučnik ne treba da se pita o mogućim } \\
\text { posledicama svojih istraživanja i otkrića. }\end{array}$} & \multirow{3}{*}{25} & 4 & 1 & 1 & 2 & 2 & 2 & 2.00 \\
\hline & & 2 & 2 & 2 & 2 & 5 & 2 & 2.50 \\
\hline & & -2 & 1 & 1 & 0 & 3 & 0 & 0.50 \\
\hline \multirow{3}{*}{$\begin{array}{c}\text { Isključivo naučno-tehnički napredak poboljšaće } \\
\text { sveopšti životni standard. }\end{array}$} & \multirow{3}{*}{31} & 4 & 3 & 4 & 4 & 3 & 3 & 3.50 \\
\hline & & 3 & 2 & 4 & 1 & 3 & 3 & 2.67 \\
\hline & & -1 & -1 & 0 & -3 & 0 & 0 & -0.83 \\
\hline \multirow{3}{*}{$\begin{array}{l}\text { Naučne metode mogu uvek da se svedu na } \\
\text { neposredno iskustvo. }\end{array}$} & \multirow{3}{*}{37} & 2 & 1 & 3 & 2 & 4 & 4 & 2.67 \\
\hline & & 2 & 3 & 5 & 2 & 3 & 3 & 3.00 \\
\hline & & 0 & 2 & 2 & 0 & -1 & -1 & 0.33 \\
\hline \multirow[t]{3}{*}{ Nauka i filozofija imaju istu sferu proučavanja. } & \multirow{3}{*}{38} & 2 & 2 & 4 & 2 & 2 & 3 & 2.50 \\
\hline & & 2 & 2 & 4 & 2 & 4 & 3 & 2.83 \\
\hline & & 0 & 0 & 0 & 0 & 2 & 0 & 0.33 \\
\hline \multirow{3}{*}{$\begin{array}{l}\text { Prirodno-tehničke nauke verno opisuju } \\
\text { stvarnost kakva ona jeste. }\end{array}$} & \multirow{3}{*}{44} & 4 & 2 & 3 & 2 & 3 & 2 & 2.67 \\
\hline & & 2 & 3 & 3 & 1 & 3 & 3 & 2.50 \\
\hline & & -2 & 1 & 0 & -1 & 0 & 1 & -0.17 \\
\hline \multirow{3}{*}{$\begin{array}{l}\text { Prirodno-tehničke nauke pouzdanije su od } \\
\text { društveno-humanističkih. }\end{array}$} & \multirow{3}{*}{46} & 4 & 3 & 3 & 2 & 2 & 2 & 2.67 \\
\hline & & 4 & 4 & 4 & 2 & 5 & 3 & 3.67 \\
\hline & & 0 & 1 & 1 & 0 & 3 & 1 & 1.00 \\
\hline \multirow{3}{*}{$\begin{array}{l}\text { lako nisu sasvim pouzdane, induktivne metode } \\
\text { neophodne su u empirijskim naukama. }\end{array}$} & \multirow{3}{*}{50} & 4 & 5 & 3 & 4 & 4 & 3 & 3.83 \\
\hline & & 4 & 5 & 4 & 4 & 4 & 4 & 4.17 \\
\hline & & 0 & 0 & 1 & 0 & 0 & 1 & 0.33 \\
\hline \multirow{3}{*}{$\begin{array}{l}\text { Postoje pitanja koje ne mogu biti (samo) } \\
\text { naučno odgovorena. }\end{array}$} & \multirow{3}{*}{55} & 4 & 4 & 5 & 4 & 5 & 4 & 4.33 \\
\hline & & 4 & 3 & 5 & 5 & 3 & 4 & 4.00 \\
\hline & & 0 & -1 & 0 & 1 & -2 & 0 & -0.33 \\
\hline \multirow{3}{*}{$\begin{array}{c}\text { Postoji linija nesumnjivog napretka u naučnom } \\
\text { razvitku. }\end{array}$} & 60 & 4 & 4 & 5 & 4 & 3 & 4 & 4.00 \\
\hline & OU & 4 & 4 & 5 & 4 & 3 & 4 & 4.00 \\
\hline & & 0 & 0 & 0 & 0 & 0 & 0 & 0.00 \\
\hline Naučno-tehnološki razvitak ide naporedno sa & 64 & 4 & 2 & 3 & 2 & 1 & 4 & 2.67 \\
\hline moralnim razvitkom čovečanstva. & 04 & 3 & 2 & 1 & 2 & 2 & 3 & 2.17 \\
\hline & & -1 & 0 & -2 & 0 & 1 & -1 & -0.50 \\
\hline
\end{tabular}




\section{Група питања A}

Став 1: На сва питања човечанства се може одговорити научно, то је само питање тренутног стадијума развитка науке.

Крајњи податак 0,00 резултат је непромењеног укупног броја поена у првом $(2,67)$ и другом анкетирању $(2,67)$. Уколико се уђе у обраду конкретних одговора појединаца може се приметити да поверење у науку или расте или незнатно слаби. Али будући да су укупни одговори свих анкетираних у оба тестирања испод 3 закључујемо да бруцоши генерално не верују да наука може дати одговоре на сва релевантна питања.

Став 5: Искључиво научно-технички напредак побољшаће свеопшти животни стандард.

Укупан резултат $-0,83$ производ је разлике броја поена у првом $(3,50)$ и другом анкетирању $(2,67)$. Добијени резултати сведоче о губљењу вере у то да ће нам научно-технолошки напредак омогућити квалитетнији начин живота.

Став 7: Наука и филозофија имају исту сферу проучавања.

Укупан резултат 0,33 продукт је разлике броја поена у првом $(2,50)$ и другом анкетирању $(2,83)$. У целини гледано студенти су делимично редиговали своје ставове у правцу све већег прихватања тематске сличности филозофије и науке, али будући да су оба одговора била испод 3 истичу се видне предметне разлике филозофије и науке.

Став 8: Природно-техничке науке верно описују стварност каква она јесте.

Укупан резултат 1,00 продукт је разлике броја поена у првом $(2,67)$ и другом анкетирању $(3,67)$. Студенти су све уверенији у тачност и поузданост научних резултата. Најуочљивији је помак код оних неутралних чије поверење у науку расте.

Став 11: Постоје питања на која се не може (само) научно одговорити.

Укупан резултат $-0,33$ продукт је разлике броја поена на првом $(4,33)$ и другом анкетирању $(4,00)$. У оквиру одговора на овај став студенти су остали у оквирима уверења да поред науке постоје и друге легитимне области духа које дају аутономне одговоре на релевантна питања.

\section{Група питања, Б}

Став 2: Резултати природно-техничких наука имају директнији утицај на наш живот од друштвено-хуманистичких.

Укупан скор 0,00 резултат је изостанка разлике броја поена у првом $(3,17)$ и другом анкетирању $(3,17)$. Гледано збирно нису промењени ставови у вези са овом тезом, али појединачно посматрано дошло је до различитих резултата. Генерални закључак је да су студенти спремнији да истакну утицај природних наука на наш живот него друштвено-хуманистичких.

Став 3: Примена метода природних наука на друштвене и хуманистичке науке дала би значајне и поуздане одговоре на питања тих наука. 
Укупан резултат -0,17 продукт је разлике броја поена на првом $(2,50)$ и другом анкетирању $(2,33)$. Студенти не мисле да би примена метода природних наука допринела поузданости резултата у друштвеним наукама и како време одмиче они се све више учвршћују у овом ставу.

Став 9: Природно-техничке науке поузаније су од друштвено-хуманистичких.

Укупан резултат 1,00 продукт је разлике броја поена на првом $(2,67)$ и другом анкетирању $(3,67)$. Добијени резултати су показали да је код свих студената уочен помак у правцу усвајања оних принципа који одликују научно знање као што су прецизност, поузданост и егзактност научних резултата.

\section{Група питања Ц}

Став 4: Научник не треба да се пита о могућим последицама својих истраживања и открића.

Резултат 0,50 последица је разлике броја поена у првом $(2,00)$ и другом анкетирању $(2,50)$. Будући да је у оба тестирања укупан број одговора био испод 3,00 евидентно је да бруцоши сматрају како научник у свом раду мора увек да има високу свест о могућим негативним последицама својих истраживања и открића.

\section{Група питања Д}

Став 6: Научне методе могу увек да се сведу на непосредно искуство.

Укупан резултат 0,33 производ је разлике броја поена у првом $(2,67)$ и другом анкетирању $(3,00)$. Одговор на овај став који је требало да гласи Научне теорије могу увек да се сведу на непосредно искуство у другом одговору се примакао збирном одговору 3 што у крајњој мери говори да је за формирање става поводом овог стручног питања, које се тиче позитивистичког учења, потребно конкретно знање из области филозофије науке. Наиме, бруцоши су најчешће одговарали како на овако формулисан став углавном немају јасан и недвосмислен одговор.

Став 10: Иако нису сасвим поуздане, индуктивне методе неопходне су у емпиријским наукама.

Укупан резултат 0,33 настао је на основу разлике броја поена на првом $(3,83)$ и другом анкетирању $(4,17)$. Висок постотак афирмативних одговора на ово питање говори о исправном знању о природи индуктивне методе и њеном месту у модерној науци, а помак од 0,33 сведочи да се од семестра до семестра повећава знање студената о овој теми.

\section{Група питања Е}

Став 12: Постоји линија несумњивог напретка у научном развитку.

Крајњи резултат 0,00 показује исти број поена на првом $(4,00)$ и другом анкетирању $(4,00)$. Сви испитаници су заокружили идентичне резултате након 
другог анкетирања у односу на своје раније одговоре. Студенти су показали високо слагање са тврдњом да се наука стално развија и усавршава.

Став 13: Научно-технолошки развитак иде напоредно са моралним развитком човечанства.

Резултат -0,50 продукт је односа броја поена у првом $(2,67)$ и другом анкетирању $(2,17)$. Након два семестра рада студенти су још мање уверени да научно-технолошки развитак доприноси и моралном развитку људи.

\section{II. Анализа одговора студената друге године}

У оквиру друге године проучава се средњовековна филозофија. Ово је период у историји када се други облици сазнања, пре свега религијско, више уважавају од научног. Филозофија је у овом периоду под великим утицајем теологије. У том смислу занимљиво је пратити ставове студената с обзиром на могући утицај учења византијских и западних теолога на сагледавање позиције и значаја науке.

\section{Табела резултата одговора студената друге године}

\begin{tabular}{|c|c|c|c|c|c|c|c|c|c|c|}
\hline & \multicolumn{8}{|c|}{ II godina } & \\
\hline & & 10005 & 10025 & 11020 & 07030 & 07040 & 12060 & 08010 & 09035 & \\
\hline \multirow{2}{*}{$\begin{array}{l}\text { Na sva pitanja čovečanstva se može odgovoriti } \\
\text { naučno, to je samo pitanje trenutnog } \\
\text { stadijuma razvitka nauke. }\end{array}$} & 7 & $\begin{array}{l}1 \\
2 \\
\end{array}$ & $\begin{array}{l}3 \\
3 \\
\end{array}$ & $\begin{array}{l}4 \\
5 \\
\end{array}$ & $\begin{array}{l}2 \\
1 \\
\end{array}$ & $\begin{array}{l}4 \\
3 \\
\end{array}$ & $\begin{array}{l}1 \\
1 \\
\end{array}$ & $\begin{array}{l}2 \\
2 \\
\end{array}$ & $\begin{array}{r}2 \\
3 \\
\end{array}$ & $\begin{array}{l}2.38 \\
2.50\end{array}$ \\
\hline & & 1 & 0 & 1 & -1 & -1 & 0 & 0 & 1 & 0.13 \\
\hline \multirow{2}{*}{$\begin{array}{l}\text { Rezultati prirodno-tehničkih nauka imaju } \\
\text { direktniji uticaj na naš život od društveno- } \\
\text { humanističkih. }\end{array}$} & 12 & $\begin{array}{l}4 \\
5 \\
\end{array}$ & $\begin{array}{l}1 \\
2 \\
\end{array}$ & $\begin{array}{l}3 \\
1\end{array}$ & $\begin{array}{l}2 \\
2 \\
\end{array}$ & \begin{tabular}{l|l}
3 \\
2 \\
\end{tabular} & $\begin{array}{l}1 \\
3 \\
\end{array}$ & $\begin{array}{l}2 \\
4 \\
\end{array}$ & \begin{tabular}{l|l}
3 \\
3 \\
\end{tabular} & $\begin{array}{l}2.38 \\
2.75 \\
\end{array}$ \\
\hline & & 1 & 1 & -2 & 0 & -1 & 2 & 2 & 0 & 0.38 \\
\hline \multirow{2}{*}{$\begin{array}{l}\text { Primena metoda prirodnih nauka na društvene } \\
\text { i humanističke nauke dala bi značajne i } \\
\text { pouzdane odgovore na pitanja tih nauka. }\end{array}$} & 18 & $\begin{array}{l}2 \\
2 \\
\end{array}$ & $\begin{array}{r}2 \\
3 \\
\end{array}$ & $\begin{array}{l}5 \\
5 \\
\end{array}$ & $\begin{array}{l}2 \\
1 \\
\end{array}$ & $\begin{array}{l}2 \\
4 \\
\end{array}$ & $\begin{array}{r}3 \\
3 \\
\end{array}$ & $\begin{array}{l}1 \\
2 \\
\end{array}$ & $\begin{array}{l}1 \\
2 \\
\end{array}$ & $\begin{array}{l}2.25 \\
2.75 \\
\end{array}$ \\
\hline & & 이 & 1 & 0 & -1 & 2 & 0 & 1 & 1 & 0.50 \\
\hline \multirow[t]{2}{*}{$\begin{array}{l}\text { Naučnik ne treba da se pita o mogućím } \\
\text { posledicama svojih istraživanja i otkrića. }\end{array}$} & 25 & $\begin{array}{l}1 \\
1\end{array}$ & $\begin{array}{l}3 \\
3 \\
\end{array}$ & $\begin{array}{l}1 \\
1\end{array}$ & $\begin{array}{l}2 \\
2\end{array}$ & $\begin{array}{l}1 \\
1\end{array}$ & $\begin{array}{l}2 \\
3\end{array}$ & $\begin{array}{l}1 \\
2\end{array}$ & $\begin{array}{l}1 \\
1\end{array}$ & $\begin{array}{l}1.50 \\
1.75 \\
\end{array}$ \\
\hline & & 이 & 이 & 0 & 0 & 이 & 1 & 1 & 이 & 0.25 \\
\hline \multirow[t]{2}{*}{$\begin{array}{l}\text { Isključivo naučno-tehnički napredak poboljšaće } \\
\text { sveopšti životni standard. }\end{array}$} & 31 & $\begin{array}{l}1 \\
2\end{array}$ & $\begin{array}{l}3 \\
2 \\
\end{array}$ & $\begin{array}{l}1 \\
1 \\
\end{array}$ & $\begin{array}{l}1 \\
1\end{array}$ & $\begin{array}{l}2 \\
1 \\
\end{array}$ & $\begin{array}{l}1 \\
1 \\
\end{array}$ & $\begin{array}{l}3 \\
4 \\
\end{array}$ & $\begin{array}{l}3 \\
2 \\
\end{array}$ & $\begin{array}{l}1.88 \\
1.75 \\
\end{array}$ \\
\hline & & 1 & -1 & 0 & 0 & -1 & 0 & 1 & -1 & -0.13 \\
\hline \multirow[t]{2}{*}{$\begin{array}{l}\text { Naučne metode mogu uvek da se svedu na } \\
\text { neposredno iskustvo. }\end{array}$} & 37 & $\begin{array}{l}1 \\
2 \\
\end{array}$ & $\begin{array}{l}2 \\
4 \\
\end{array}$ & $\begin{array}{l}3 \\
1 \\
\end{array}$ & $\begin{array}{l}3 \\
3 \\
\end{array}$ & $\begin{array}{l}3 \\
4 \\
\end{array}$ & $\begin{array}{l}1 \\
3 \\
\end{array}$ & $\begin{array}{l}3 \\
2 \\
\end{array}$ & $\begin{array}{l}3 \\
3 \\
\end{array}$ & $\begin{array}{l}2.38 \\
2.75 \\
\end{array}$ \\
\hline & & 1 & 2 & -2 & 0 & 1 & 2 & -1 & 0 & 0.38 \\
\hline \multirow[t]{2}{*}{ Nauka i filozofija imaju istu sferu proučavanja. } & 38 & \begin{tabular}{l|l}
4 \\
3
\end{tabular} & $\begin{array}{l}3 \\
3 \\
\end{array}$ & $\begin{array}{l}5 \\
5\end{array}$ & \begin{tabular}{l|l}
3 \\
2
\end{tabular} & $\begin{array}{l}1 \\
4 \\
\end{array}$ & $\begin{array}{l}2 \\
4 \\
\end{array}$ & $\begin{array}{l}3 \\
2 \\
\end{array}$ & $\begin{array}{r}2 \\
2 \\
\end{array}$ & $\begin{array}{l}2.88 \\
3.13 \\
\end{array}$ \\
\hline & & -1 & 0 & 0 & -1 & 3 & 2 & -1 & 0 & 0.25 \\
\hline \multirow[t]{2}{*}{$\begin{array}{l}\text { Prirodno-tehničke nauke verno opisuju } \\
\text { stvarnost kakva ona jeste. }\end{array}$} & 44 & $\begin{array}{l}2 \\
3 \\
\end{array}$ & $\begin{array}{r}2 \\
3 \\
\end{array}$ & $\begin{array}{l}4 \\
5 \\
\end{array}$ & $\begin{array}{l}3 \\
2 \\
\end{array}$ & $\begin{array}{l}2 \\
2 \\
\end{array}$ & $\begin{array}{l}1 \\
2 \\
\end{array}$ & $\begin{array}{l}4 \\
4 \\
\end{array}$ & $\begin{array}{l}3 \\
4 \\
\end{array}$ & $\begin{array}{l}2.63 \\
3.13 \\
\end{array}$ \\
\hline & & 1 & 1 & 1 & -1 & 0 & 1 & 0 & 1 & 0.50 \\
\hline \multirow[t]{2}{*}{$\begin{array}{l}\text { Prirodno-tehničke nauke pouzdanije su od } \\
\text { društveno-humanističkih. }\end{array}$} & 46 & $\begin{array}{l}4 \\
4 \\
\end{array}$ & $\begin{array}{l}2 \\
2 \\
\end{array}$ & $\begin{array}{l}5 \\
5 \\
\end{array}$ & $\begin{array}{l}3 \\
2 \\
\end{array}$ & $\begin{array}{l}4 \\
2 \\
\end{array}$ & $\begin{array}{l}3 \\
3 \\
\end{array}$ & $\begin{array}{l}2 \\
4 \\
\end{array}$ & $\begin{array}{l}3 \\
4 \\
\end{array}$ & $\begin{array}{r}3.25 \\
3.25 \\
\end{array}$ \\
\hline & & 0 & 0 & 0 & -1 & -2 & 0 & 2 & 1 & 0.00 \\
\hline \multirow[t]{2}{*}{$\begin{array}{l}\text { lako nisu sasvim pouzdane, induktivne metode } \\
\text { neophodne su u empirijskim naukama. }\end{array}$} & 50 & $\begin{array}{l}5 \\
5 \\
\end{array}$ & $\begin{array}{l}4 \\
4 \\
\end{array}$ & $\begin{array}{l}5 \\
5 \\
\end{array}$ & $\begin{array}{l}3 \\
3 \\
\end{array}$ & $\begin{array}{l}5 \\
5 \\
\end{array}$ & $\begin{array}{l}5 \\
5 \\
\end{array}$ & $\begin{array}{l}4 \\
5 \\
\end{array}$ & $\begin{array}{l}3 \\
4 \\
\end{array}$ & $\begin{array}{l}4.25 \\
4.50 \\
\end{array}$ \\
\hline & & 0 & 0 & 0 & 0 & 0 & 0 & 1 & 1 & 0.25 \\
\hline \multirow[t]{2}{*}{$\begin{array}{l}\text { Postoje pitanja koje ne mogu biti (samo) } \\
\text { naučno odgovorena. }\end{array}$} & 55 & $\begin{array}{l}4 \\
5 \\
\end{array}$ & $\begin{array}{l}3 \\
4 \\
\end{array}$ & \begin{tabular}{l|l} 
\\
5
\end{tabular} & \begin{tabular}{l|l}
3 \\
5
\end{tabular} & $\begin{array}{l}4 \\
5 \\
\end{array}$ & $\begin{array}{l}5 \\
4 \\
\end{array}$ & $\begin{array}{l}5 \\
5 \\
\end{array}$ & $\begin{array}{l}3 \\
4 \\
\end{array}$ & $\begin{array}{l}3.50 \\
4.63 \\
\end{array}$ \\
\hline & & 1 & 1 & 4 & 2 & 1 & -1 & 0 & 1 & 1.13 \\
\hline \multirow[t]{2}{*}{$\begin{array}{l}\text { Postoji linija nesumnjivog napretka u naučnom } \\
\text { razvitku. }\end{array}$} & 60 & $\begin{array}{l}3 \\
4 \\
\end{array}$ & $\begin{array}{l}3 \\
3 \\
\end{array}$ & $\begin{array}{l}5 \\
5\end{array}$ & $\begin{array}{l}4 \\
3 \\
\end{array}$ & $\begin{array}{l}3 \\
2 \\
\end{array}$ & $\begin{array}{l}2 \\
3 \\
\end{array}$ & $\begin{array}{l}3 \\
4 \\
\end{array}$ & $\begin{array}{l}4 \\
4 \\
\end{array}$ & $\begin{array}{l}3.38 \\
3.50 \\
\end{array}$ \\
\hline & & 1 & 0 & 0 & -1 & -1 & 1 & 1 & 0 & 0.13 \\
\hline \multirow[t]{2}{*}{$\begin{array}{l}\text { Naučno-tehnološki razvitak ide naporedno sa } \\
\text { moralnim razvitkom čovečanstva. }\end{array}$} & 64 & $\begin{array}{l}2 \\
1\end{array}$ & \begin{tabular}{l|l}
3 \\
3 \\
\end{tabular} & $\begin{array}{l}1 \\
4\end{array}$ & $\begin{array}{l}1 \\
1\end{array}$ & $\begin{array}{l}2 \\
1\end{array}$ & \begin{tabular}{l|l}
1 \\
2 \\
\end{tabular} & \begin{tabular}{l|l}
3 \\
2
\end{tabular} & $\begin{array}{l}3 \\
2 \\
\end{array}$ & $\begin{array}{l}2.00 \\
2.00\end{array}$ \\
\hline & & -1 & 0 & 3 & 0 & -1 & 1 & -1 & -1 & 0.00 \\
\hline
\end{tabular}




\section{Група питања A}

Став1: На сва питања човечанства се може одговорити научно, то је само питане тренутног стадијума развитка науке.

Укупан резултат 0,13 производ је односа броја поена у првом $(2,38)$ и другом анкетирању $(2,50)$. Уколико се уђе у обраду конкретних одговора појединаца може се приметити да поверење у науку незнатно расте. С обзиром да су одговори свих анкетираних у оба тестирања испод 3 евидентно је да студенти друге године немају висок ниво поверења у домете науке.

Став 5: Искључиво научно-технички напредак побољшаће свеопшти животни стандард.

Укупан резултат -0,13 однос је разлике броја поена на првом $(1,88)$ и другом анкетирању $(1,75)$. Добијени резултати сведоче о уверењу да наука не омогућава људима безбрижан живот будући да вероватно ствара бројне проблеме који трајно ремете квалитет живљења.

Став 7: Наука и филозофија имају исту сферу проучавања.

Укупан резултат 0,25 однос је разлике броја поена на првом $(2,88)$ и другом анкетирању $(3,13)$. Збирно гледано студенти су незнатно променили своје ставове у правцу све већег прихватања предметне сличности филозофије и науке, али уколико се упореде појединачни одговори промене које су наступиле више говоре о интерпретативним разликама у мишљењу испитаника, будући да исти број студената говори у прилог ове тезе као и против ње.

Став 8: Природно-техничке науке верно описују стварност каква она jecme.

Укупан скор 0,50 производ је разлике броја поена на првом $(2,63)$ и другом анкетирању $(3,13)$. Студенти су уверенији у поузданост научних описа и објашњења стварности али ти помаци су невелики.

Став 11: Постоје питања која не могу бити (само) научно одговорена.

Крајњи резултат 1,13 показатељ је разлике броја поена на првом $(3,50)$ и другом анкетирању $(4,63)$. Упоређујући резултате првог и другог семестра јасно је да студенти све више увиђају да поред науке постоје и друге области духа које могу дати одговоре значајне за живот појединца. Након овако високог резултата $(4,63)$ другог анкетирања и значајне разлике између збира првог и другог семестра $(1,13)$ можемо да закључимо да су утицаји других курсева филозофије, нарочито Филозофије средњег века 1 и 2, у значајној мери релативизовали позицију науке у целокупном систему знања.

\section{Група питања Б}

Став 2: Резултати природно-техничких наука имају директнији утицај на наш живот од друштвено-хуманистичких.

Укупан резултат 0,38 однос је разлике броја поена на првом $(2,38)$ и другом анкетирању $(2,75)$. Са изнетим ставом о утицају природних наука на наш 
живот студенти се углавном не слажу. У обе анкете укупан резултат је испод 3. Ове резултате такође објашњавамо значајним упливом учења из Средњовековне филозофије на особене концепције о знању и свету.

Став 3: Примена метода природних наука на друштвене и хуманистичке науке дала би значајне и поуздане одговоре на питања тих наука.

Коначан резултат 0,50 производ је разлике броја поена на првом $(2,25)$ и другом анкетирању $(2,75)$. Студенти не сматрају да би примена метода природних наука унапредила поузданост истраживања и резултата друштвених и хуманистичких наука. Ипак, приметно је ублажавање јачине оваквог става код већег броја испитаника.

Став 9: Природно-техничке науке поузданије су од друштвено-хуманистичких.

Резултат 0,00 показује непостојање разлике у поенима на првом $(3,25)$ и другом анкетирању $(3,25)$. Генерално гледано, студенти мало више истичу поузданост и егзактност резултата природних наука у односу на друштвене. Уколико посматрамо појединачне одговоре подједнак је број и интензитет колебања при промени ставова од афирмативног ка негативном и обрнуто.

\section{Група питања Ц}

Став 4: Научник не треба да се пита о могућим последицама својих истражсвања и открића.

Резултат 0,25 је разлика броја поена добијених у првом $(1,50)$ и другом анкетирању $(1,75)$. Будући да је у оба тестирања укупан број одговора био испод 2,00 испитаници сматрају да научници у свом раду имају велику одговорност према целокупној јавности. Њихова истраживања нужно морају да укључе свест о свим могућим последицама и продуктима научног испитивања и рада.

\section{Група питања Д}

Став 6: Научне методе могу увек да се сведу на непосредно искуство.

Збирни резултат 0,38 продукт је разлике броја поена на првом $(2,38)$ и другом анкетирању $(2,75)$. Одговор на овај став који је требало да гласи Научне теорије могу увек да се сведу на непосредно искуство је у обе анкете испод 3. Добијени резултати потврђују оно што смо желели да испитамо, да студенти, иако нису слушали курс из филозофије науке, могу да препознају нетачност овог става и непрецизност ове формулације.

Став 10: Иако нису сасвим поуздане, индуктивне методе неопходе су у емпиријским наукама.

Укупан резултат 0,25 показује разлику броја поена у првом $(4,25)$ и другом анкетирању $(4,50)$. Веома висок број изразито афирмативних одговора на ово питање сведочи о целовитом и утемељеном знању студената о поступку индуктивног закључивања. Такође, јасно је да се стечена знања из логике лако 
примењују при оцењивању доприноса који науке могу имати при употреби индуктивне методе.

\section{Група питања E}

Став 12: Постоји линија несумњивог напретка у научном развитку.

Резултат 0,13 показује пораст поена од првог $(3,38)$ до другог анкетирања $(3,50)$. Неки испитаници су заокружили идентичне одговоре, али је већи број оних који су при еволуирању свог става појачали афирмативан одговор него обрнуто, о чему сведочи и ова малена разлика од 0,13. Углавном је потврђен став да наука напредује.

Став 13: Научно-технолошки развитак иде напоредно са моралним развитком човечанства.

Резултат 0,00 говори да не постоји разлика у поенима при првом $(2,00)$ и другом анкетирању (2,00). Студенти показују значајно неслагање са ставом да научно-технолошки развитак доприноси и моралном развитку људи. У другом кругу анкетирања многи испитаници су појачали интензитет одбијања закључка овог става.

\section{III. Анализа одговора студената треће године}

У оквиру треће године курса из историје филозофије проучавају се: ренесанса, нововековна филозофија, просветитељство и немачки идеализам. Поново се јавља интересовање за проблем сазнања. Наиме, то је период у којем се заоштравају питања везана за извор, границе, могућности и домете сазнања. Гносеологија се конституише као филозофска дисциплина. Увићајући сву субјективност нашег сазнања филозофи као кључну тему постављају проналажење исправне методе која би водила поузданом сазнању. У новом веку науке се убрзано развијају и усавршавају и постају посве емпиријске и експериметалне. У оквиру предмета Филозофија науке и технике који се слуша у петом семестру студенти су у могућности да се упознају са значајним савременим концепцијама које се баве: проблемом раста и развоја научног знања, открићем и оправдањем научних теорија, позицијом науке у друштву и итд. Презентују се концепције од логичког позитивизма до савремених конструктивистичких учења.

\section{Група питања A}

Став 1: На сва питања човечанства се може одговорити научно, то је само питање тренутног стадијума развитка науке.

Укупан резултат 0,33 је однос броја поена у првом $(1,33)$ и другом анкетирању $(1,67)$. Добијени одговори показују да студенти треће године немају слепо поверење у домете и резултате науке. Разматрајући раст и развој научног знања испитаници не приступају догматски већ промишљају реално стање у науци. Такође, уочљиво је негирање универзалности ове тврдње што говори да студенти проблему апсолутних ставова прилазе с опрезом. 
Став 5: Искључиво научно-технички напредак побољшаће свеопшти животни стандард.

Укупан резултат -2,00 је разлика броја поена на првом $(3,00)$ и другом анкетирању $(1,00)$. Добијени резултати сведоче о томе да су након курса из Филозофије науке и технике студенти стекли реалнију слику о многим опасним последицама научно-техничког усмерења развоја цивилизације.

Став 7: Наука и филозофија имају исту сферу проучавања.

Резултат 0,00 продукт је непостојања разлике у поенима при првом $(3,00)$ и другом анкетирању $(3,00)$. Сви одговори свих студената треће године идентични су и у првом и у другом анкетирању. Будући да ова теза представља базично уверење о односу науке и филозофије не чуди што су студенти треће године дали идентичне одговоре. Наиме, они поред адекватног знања имају већ и изграђена стабилна уверења и ставове о кључним филозофским дилемама и питањима. jecme.

Став 8: Природно-техничке науке верно описују стварност каква она

Укупана цифра -0,33 продукт је разлике броја поена на првом $(1,67)$ и другом анкетирању $(1,33)$. Након усвојених знања из Филозофије науке и технике, али и из Гносеологије 1 и 2 студенти конструктивно промишљају проблем сазнања света. Наша слика стварности никада није пуки одраз или верни опис реалитета већ изразито лични доживљај о појавама које срећемо у искуству. Укупан број поена обе анкете није већи од 2, те је могуће закључити да студенти добро разумеју централна епистемолошка питања о разлици између појаве и ствари по себи као и проблем критеријума заснивања оправданог и истинитог веровања.

Став 11: Постоје питања која не могу бити (само) научно одговорена.

Резултат 0,00 показује непостојање разлике између укупног броја поена на првом $(5,00)$ и другом анкетирању $(5,00)$. Међутим, не само да се укупан збир није мењао него и нико од студената није променио свој став поводом овог питања. Ово је јасан показатељ да студенти током студија напредују у правцу формирања чврстих и дубоких уверења.

\section{Група питања Б}

Став 2: Резултати природно-техничких наука имају директнији утицај на наш живот од друштвено-хуманистичких.

Негативан скор -1,67 продукт је разлике броја поена на првом $(3,67)$ и другом анкетирању (2,00). Генерални став поводом питања о директнијем утицају природних наука (од друштвено-хуманистичких) на наш живот је из афирмативног прешао у одречни. Разлика се може објаснити конкретним концепцијама, са којима се студенти упознају током курса Филозофија науке и технике, које говоре о релативизацији статуса научног знања и интерпретативном карактеру научних теорија. 
Став 3: Примена метода природних наука на друштвене и хуманистичке науке дала би значајне и поуздане одговоре на питања тих наука.

Укупан број поена од -0,33 продукт је разлике броја поена у првом $(2,33)$ и другом анкетирању $(2,00)$. Студенти не сматрају да би примена метода природних наука унапредила друштвено-хуманистичке. Приметно је заоштравање овог става код већег броја испитаника.

Став 9: Природно-техничке науке поузданије су од друштвено-хуманистичких.

Укупан резултат 1,67 показује значајну разлику у поенима на првом $(3,00)$ и другом анкетирању $(1,33)$. Пре курса из Филозофије науке и технике студенти су, када је у питању поређење природно-техничких и друштвено-хуманистичких наука, најчешће имали неутралне одговоре. Изучавање филозофије науке jе код њих подстакло увид у интерпретативну и конструисану природу научних теорија и у природним наукама.

\section{Група питања Ц}

Став 4: Научник не треба да се пита о могућим последицама својих истраживања и открића.

Укупан резултат -1,33 продукт је значајне разлике броја поена на првом $(2,67)$ и другом анкетирању $(1,33)$. Испитаници сматрају да научници у свом раду морају да се питају о консеквенцама својих истраживања. Временом су студенти треће године још строже заступали овај став.

\section{Група питања Д}

Став 6: Научне методе могу увек да се сведу на непосредно искуство.

Резултат $-0,33$ је разлика броја бодова у првом $(3,00)$ и другом анкетирању $(2,67)$. Одговор на овај став, који је требало да гласи Научне теорије могу увек да се сведу на непосредно искуство, опада од 3 до 2,67. Добијени резултати потврђују оно што смо желели да испитамо, да студенти, након слушања курса из Филозофије науке и технике, могу да уоче нетачност и непрецизност овакве формулације.

Став 10: Иако нису сасвим поуздане, индуктивне методе неоподне су у емпиријским наукама.

Укупан број 0,67 продукт је односа поена на првом $(3,00)$ и другом анкетирању $(3,67)$. Помак у укупном броју остварених поена од 3,00 до 3,67 говори о продуктивно усвојеном знању поводом проблема индукције, али и о увиђању неминовности коришћења индуктивне методе у науци.

\section{Група питања E}

Став 12: Постоји линија несумњивог напретка у научном развитку.

Укупан резултат -0,33 производ је односа броја поена у првом $(3,33)$ и другом анкетирању $(3,00)$. Курс из филозофије науке довео је у питање увреже- 
но мишљење о прогресивном карактеру развоја науке. Посредно, релативизација одређених области знања делује у правцу изградње недогматског начина промишљања појава.

Став 13: Научно-технолошки развитак иде напоредно са моралним развитком човечанства.

Укупан резултат -0,67 продукт је разлике у поенима при првом $(2,00)$ и другом анкетирању $(1,33)$. Студенти се не слажу са овим ставом. Научно-технолошки развитак не доприноси и моралном развитку људи. У другом кругу анкетирања студенти су у већој мери одбацили овај став.

Табела резултата одговора студената треће године

\begin{tabular}{|c|c|c|c|c|c|}
\hline & \multicolumn{3}{|c|}{ III godina } & \\
\hline & & 28445 & 11160 & 12192 & \\
\hline \multirow{2}{*}{$\begin{array}{c}\text { Na sva pitanja čovečanstva se može odgovoriti } \\
\text { naučno, to je samo pitanje trenutnog } \\
\text { stadijuma razvitka nauke. }\end{array}$} & \multirow[t]{2}{*}{4} & $\begin{array}{l}1 \\
1\end{array}$ & $\begin{array}{l}1 \\
1\end{array}$ & $\begin{array}{l}2 \\
3\end{array}$ & \begin{tabular}{|l|}
1.33 \\
1.67
\end{tabular} \\
\hline & & $\mathrm{O}$ & 0 & 1 & 0.33 \\
\hline \multirow{2}{*}{$\begin{array}{c}\text { Rezultati prirodno-tehničkih nauka imaju } \\
\text { direktniji uticaj na naš život od društveno- } \\
\text { humanističkih. }\end{array}$} & 6 & $\begin{array}{l}3 \\
1 \\
\end{array}$ & $\begin{array}{l}5 \\
2 \\
\end{array}$ & $\begin{array}{l}3 \\
3 \\
\end{array}$ & $\begin{array}{l}3.67 \\
2.00 \\
\end{array}$ \\
\hline & & -2 & -3 & O & $-\mathbf{1 . 6 7}$ \\
\hline \multirow{2}{*}{$\begin{array}{c}\text { Primena metoda prirodnih nauka na društvene } \\
\text { i humanističke nauke dala bi značajne i } \\
\text { pouzdane odgovore na pitanja tih nauka. }\end{array}$} & 9 & $\begin{array}{l}3 \\
1 \\
\end{array}$ & $\begin{array}{l}2 \\
1 \\
\end{array}$ & $\begin{array}{l}2 \\
4 \\
\end{array}$ & $\begin{array}{l}2.33 \\
2.00 \\
\end{array}$ \\
\hline & & -2 & -1 & 2 & -0.33 \\
\hline \multirow[t]{2}{*}{$\begin{array}{l}\text { Naučnik ne treba da se pita o mogućim } \\
\text { posledicama svojih istraživanja i otkrića. }\end{array}$} & 12 & $\begin{array}{l}5 \\
1 \\
\end{array}$ & $\begin{array}{l}1 \\
1 \\
\end{array}$ & $\begin{array}{l}2 \\
2 \\
\end{array}$ & $\begin{array}{l}2.67 \\
1.33 \\
\end{array}$ \\
\hline & & -4 & $\mathrm{O}$ & $\mathrm{O}$ & -1.33 \\
\hline \multirow[t]{2}{*}{$\begin{array}{l}\text { Isključivo naučno-tehnički napredak poboljšaće } \\
\text { sveopšti životni standard. }\end{array}$} & 15 & $\begin{array}{l}5 \\
1\end{array}$ & $\begin{array}{l}1 \\
1\end{array}$ & $\begin{array}{l}3 \\
1 \\
\end{array}$ & $\begin{array}{l}3.00 \\
1.00 \\
\end{array}$ \\
\hline & & -4 & $\mathrm{O}$ & -2 & -2.00 \\
\hline \multirow[t]{2}{*}{$\begin{array}{c}\text { Naučne metode mogu uvek da se svedu na } \\
\text { neposredno iskustvo. }\end{array}$} & 18 & $\begin{array}{l}4 \\
4 \\
\end{array}$ & $\begin{array}{l}3 \\
1 \\
\end{array}$ & $\begin{array}{l}2 \\
3 \\
\end{array}$ & $\begin{array}{r}.00 \\
2.67 \\
\end{array}$ \\
\hline & & $\mathrm{O}$ & -2 & 1 & -0.33 \\
\hline \multirow[t]{2}{*}{ Nauka i filozofija imaju istu sferu proučavanja. } & 19 & $\begin{array}{l}1 \\
1 \\
\end{array}$ & $\begin{array}{l}4 \\
4 \\
\end{array}$ & $\begin{array}{l}4 \\
4 \\
\end{array}$ & \begin{tabular}{|l|}
3.00 \\
3.00 \\
\end{tabular} \\
\hline & & $\mathrm{O}$ & $\mathrm{O}$ & $\mathrm{O}$ & 0.00 \\
\hline \multirow[t]{2}{*}{$\begin{array}{l}\text { Prirodno-tehničke nauke verno opisuju } \\
\text { stvarnost kakva ona jeste. }\end{array}$} & 23 & $\begin{array}{l}1 \\
1 \\
\end{array}$ & \begin{tabular}{l|}
2 \\
1 \\
\end{tabular} & $\begin{array}{l}2 \\
2 \\
\end{array}$ & $\begin{array}{l}1.67 \\
1.33 \\
\end{array}$ \\
\hline & & $\mathrm{O}$ & -1 & O & -0.33 \\
\hline \multirow[t]{2}{*}{$\begin{array}{c}\text { Prirodno-tehničke nauke pouzdanije su od } \\
\text { društveno-humanističkih. }\end{array}$} & 25 & $\begin{array}{l}4 \\
1 \\
\end{array}$ & $\begin{array}{l}2 \\
1 \\
\end{array}$ & $\begin{array}{l}3 \\
2 \\
\end{array}$ & $\begin{array}{l}.00 \\
1.33 \\
\end{array}$ \\
\hline & & -3 & -1 & -1 & -1.67 \\
\hline \multirow[t]{2}{*}{$\begin{array}{c}\text { lako nisu sasvim pouzdane, induktivne metode } \\
\text { neophodne su u empirijskim naukama. }\end{array}$} & 26 & $\begin{array}{l}4 \\
4 \\
\end{array}$ & $\begin{array}{l}1 \\
4 \\
\end{array}$ & $\begin{array}{l}4 \\
3 \\
\end{array}$ & $\begin{array}{r}3.00 \\
3.67 \\
\end{array}$ \\
\hline & & $\mathrm{O}$ & 3 & -1 & 0.67 \\
\hline \multirow[t]{2}{*}{$\begin{array}{l}\text { Postoje pitanja koje ne mogu biti (samo) } \\
\text { naučno odgovorena. }\end{array}$} & 29 & $\begin{array}{l}5 \\
5 \\
\end{array}$ & $\begin{array}{l}5 \\
5 \\
\end{array}$ & $\begin{array}{l}5 \\
5 \\
\end{array}$ & $\begin{array}{l}5.00 \\
5.00 \\
\end{array}$ \\
\hline & & $\mathrm{O}$ & 0 & O & 0.00 \\
\hline \multirow[t]{2}{*}{$\begin{array}{c}\text { Postoji linija nesumnjivog napretka u naučnom } \\
\text { razvitku. }\end{array}$} & 32 & $\begin{array}{l}5 \\
4 \\
\end{array}$ & $\begin{array}{l}1 \\
1 \\
\end{array}$ & $\begin{array}{l}4 \\
4 \\
\end{array}$ & $\begin{array}{l}3.33 \\
3.00 \\
\end{array}$ \\
\hline & & -1 & O & O & -0.33 \\
\hline \multirow[t]{2}{*}{$\begin{array}{c}\text { Naučno-tehnološki razvitak ide naporedno sa } \\
\text { moralnim razvitkom čovečanstva. }\end{array}$} & 35 & $\begin{array}{l}1 \\
1 \\
\end{array}$ & $\begin{array}{l}2 \\
1 \\
\end{array}$ & $\begin{array}{l}3 \\
2 \\
\end{array}$ & $\begin{array}{l}2.00 \\
1.33 \\
\end{array}$ \\
\hline & & $\mathrm{O}$ & -1 & -1 & -0.67 \\
\hline
\end{tabular}




\section{Закључак}

На основу свих добијених резултата можемо да закључимо и истакнемо следећа запажања:

Иако верују у поузданост научног знања студенти прве године истичу да она није свемоћна, мада има велики уплив на наш живот. Њен развој је непрекидан, али нам он не чини живот квалитетнијим нити ми постајемо моралнији. Напротив, са све већим степеном развоја науке расте и одговорност научника за последице примене научних открића.

Кроз своје одговоре, студенти друге године су показали велико уважавање других духовних делатности и области знања који обликују наше ставове и начин живота. Наука није она област која нас чини моралнијим и бољим. Иако признају да наука стално напредује приметна је све већа релативизација вредности научних достигнућа. Чини се да она ствара већи број проблема него што решава или бар да са развојем науке расте и број проблема са којима се суочавамо.

Најзначајнији закључак о ставовима и начину размишљања студената треће године је да у њиховим одговорима нема догматизма и слепог поверења у науку. Међутим, ова анкета је потврдила још једну важну чињеницу. Студенти кроз одређена филозофска учења али и читав студиј полако и темељно формирају, поводом важних питања, властито уверење. Они граде чврсте ставове и убеђења и спремни су да их аргументима бране. Напредују у правцу стварања дубоких и стабилних уверења. Када се упореде резултати прве и друге анкете у њиховим одговорима има најмање одступања у врсти става. Мења се само интензитет уверења. Студенти треће године су изградили реалну слику о дометима и природи научног знања. Реално сагледавају природу индукције и њено место у поступцима научног рада. Имају високу свест о могућим последицама некритичког развоја и примене науке.

И да закључимо, на уверења студената директно утичу знања која су повезана са садржајем тих ставова. С повећањем знања мењају се и опредељења. Такође, приметан је и посредан утицај сродних учења и идеја. Знање доприноси формирању ставова а дугорочно гледано процес образовања утемељује и продубљује наша уверења.

\section{ANALYSIS OF THE RESULTS OF SURVEYS ON STUDENT ATTITUDES REGARDING QUESTIONS FROM THE METHODOLOGY AND PHILOSOPHY OF SCIENCE}

Abstract: The aim of this paper is to make a qualitative and quantitative analysis of the results of the project, which was carried out in the framework of research work at the Faculty of Philosophy, University of Niš, in order to monitor the work of students and evaluate the effects of courses in philosophy on the formation and change of student attitudes. Our basic question is whether the newly acquired knowledge of methodology 
and philosophy of science affect students' beliefs. If this effect is visible, in what direction and in what intensity does it go? We used the survey as a research method and a comparative and statistical method for data processing. The results we obtained confirmed the assumption, which we wanted to examine, of the significant influence of philosophy courses on the formation of student attitudes. Acquired knowledge of methodology and philosophy of science work to strengthen critical awareness and nondogmatic approach when considering specific problems. The results are in accordance with the theoretical orientation of the whole study of philosophy as well as the specific aims of the courses (presented in syllabuses).

Keywords: philosophy, science, philosophy of science, methodology, attitudes, knowledge, critique. 